\title{
O DIABO NA RUA, NO MEIO DO REDEMOINHO: OLHARES SOBRE O ESPAÇO RURAL A PARTIR DA PAISAGEM, DA PERCEPÇÃO E DA ARTE
}

\author{
EL DIABLO EN LA CALLE, EN MEDIO DEL TORBELLINO: MIRADAS EN EL \\ ESPACIO RURAL A PARTIR DEL PAISAJE, DE LA PERCEPCIÓN Y DEL ARTE
}

\section{THE DEVIL IN THE STREET, IN THE MIDDLE OF WHIRLPOOL: VIEWS OF THE RURAL SPACE FROM THE LANDSCAPE, PERCEPTION AND ART}

\section{Ivair Gomes ${ }^{1}$ \\ Pesquisador da Empresa de Pesquisa Agropecuária de Minas Gerais-EPAMIG \\ ivair@epamig.br}

Resumo: Partindo da premissa de que o espaço rural é um espaço ainda presente neste início de século XXI, este trabalho busca formas de visualizá-lo ou, mais exatamente, formas de percebê-lo. Primeiro é feita uma revisão bibliográfica, dando ênfase (mas não exclusividade) a trabalhos recentemente publicados na Europa. Destes destacam-se os estudos da paisagem e da percepção como conceitos centrais. Numa segunda etapa do trabalho discute-se o conceito de espaço, onde o conceito de "espaço relativo" de Leibniz aparece como base para seu entendimento. Por fim é feita uma proposta de entendimento de espaço rural a partir de obras de P. Cézanne. Neste caso o rural seria visto a partir da percepção, que pode se alterar de acordo com o momento, ou seja, o espaço não é rural, mas está rural.

Palavras-chave: Espaço Rural, Paisagem, Espaço Relativo, Percepção, Pósmodernidade

Resumen: Considerándose que el espacio rural es un espacio todavía presente en este principio del siglo $\mathrm{XXI}$, este trabajo busca formas para visualizarlo 0 , más exactamente, formas para percibirlo. Primero una revisión bibliográfica se hace, dando énfasis (pero no exclusividad) a los trabajos publicados recientemente en la Europa. De éstos los estudios del paisaje y de la percepción se distinguen como conceptos centrales. En una segunda etapa del trabajo se discute el concepto de espacio, donde

\footnotetext{
${ }^{1}$ Doutorando pela UFF - Universidade Federal Fluminense
} 
el concepto de "espacio relativo" de Leibniz aparece como base para su comprensión. Finalmente se hace una tentativa de comprensión del espacio rural en la obra de P. Cézanne. En esto caso el rural fuera visto a partir de la percepción, ése puede cambiar de acuerdo con el momento, es decir, el espacio no es rural, sino que está rural.

Palabra-clave: Espacio Rural, Paisaje, Espacio Relativo, Percepción, Pós-Modernidad

Abstract: Starting from the premise that the rural space is a space still present at the beginning of the 21st century, this article searches ways to view it or, more exactly, ways to perceive it. First, a bibliographic review is made, emphasizing (but nonexclusively) recently published works in Europe. These include studies of the landscape and perception as central concepts. The second part of this article discusses about the concept of space, using the concept of "relative space" of Leibniz as a basis for its understanding. Finally is made a proposal for understanding the rural space from the works by P. Cézanne. In this case the rural would be seen from the perception, which may change according to the moment, i.e. the space is not rural, but it is.

Keywords: Rural Space, Landscape, Relative Space, Perception, Postmodernity

\section{1 - "O diabo na rua, no meio do redemoinho"}

Marshall Berman, já nas páginas iniciais de sua famosa obra, "tudo que é sólido desmancha no ar" (Companhia das Letras, 2005), ao apresentar Rousseau e sua definição de "moderno", termina o parágrafo com uma questão: "como era, para o individuo, mover-se e viver em meio ao redemoinho ( $p 17)$ ?" Talvez seja essa a grande questão que os geógrafos, sociólogos e demais estudiosos que se dedicam ao estudo do espaço rural e às mudanças pelo qual ele tem passado, deveriam estar se fazendo nesse momento. É difícil analisar qualquer acontecimento quando estamos no meio do redemoinho ou do turbilhão de acontecimentos que fazem parte dessa mudança.

Durante muito tempo o rural foi simplesmente sinônimo de campo, talvez mais pela dificuldade de conceituar urbano que pela dificuldade de definir o espaço rural. Atualmente há um "redemoinho", na verdade um verdadeiro "turbilhão" de mudanças ocorrendo no rural. Não é incomum, por exemplo, deparar-se com aqueles que apregoam o fim do rural. Para eles o urbano se transformou na única forma de pensar o espaço. Uma outra vertente de pesquisadores mantém um direcionamento para a 
dicotomia das relações rurais/urbanas, vistas como opostas. O rural seria distinto, separado, isolado ou simplesmente o oposto do urbano. Há também os que trabalham com o conceito de espaços múltiplos e inter-relacionados ou ainda pesquisadores que se dedicam ao estudo da diferenciação de paisagens como forma de compreender seus múltiplos espaços.

Assim, na tentativa de um entendimento do que é espaço rural, diferenciando-o do urbano, percebe-se a existência de uma tensão constante entre o que vem a ser essencial e 0 acidental, entre 0 efêmero e 0 eterno, entre essência e aparência. A existência de uma multiplicidade de olhares para se discernir rural de urbano implica em exercitar a racionalidade; e exercitar a racionalidade implica em exercitar os conflitos e o contraditório.

Diante desse turbilhão que a modernidade (ou pós-modernidade?) tem nos oferecido, o presente trabalho procura fazer alguns resgates teóricos sobre essa temática; propõe uma visão para o conceito de espaço rural a partir da percepção e, por fim, faz uma analogia entre a arte e as formas de se perceber a paisagem rural.

\section{2 - Espaço Rural e Relações rural/urbanas}

O "Journal of Rural Studies" tem publicado, nos últimos 15 anos vários trabalhos acerca da diferenciação entre espaço urbano e espaço rural, dentre os quais destacam-se aqui seis artigos.

\section{1 - Localidade e representação social}

Iniciando seu artigo, K. H. Halfacree (1993) descreve quais são as 16 relações fundamentais necessárias à definição de rural exigidas pelo Department of the Environment da Inglaterra (relações estatísticas, administrativas, regiões funcionais, áreas de contato, agricultura e tamanho/densidade populacional, etc.). Halfacree lembra que Louis Wirth, ainda em 1938, propôs definições sócio-culturais que correlacionavam atributos sociais e espaciais. Neste caso, por exemplo, o urbano se caracterizaria pela "way of life", seria móvel, instável e impessoal e os contatos se dariam em função de situações temporais específicas (trabalho, casa, lazer), enquanto que o rural se caracterizaria pela estabilidade, integração e rígida estratificação social. 
Outro atores admitiam que a densidade populacional, o comportamento e as atitudes das pessoas assumiriam uma correlação entre atributos sociais e espaciais (tabela 01).

\begin{tabular}{|l|l|l|}
\hline Dicotomia rural/urbana & Rural \\
\hline Autor & Urbano & Sacro \\
\hline Becker & Secular & Solidariedade mecânica \\
\hline Durkheim & Solidariedade orgânica & Status \\
\hline Maine & Contrato & Folclore \\
\hline Redfield & Urbano & Militar \\
\hline Spencer & Industrial & Gemeinschaft \\
\hline Tonnies & Gesellschaft & Tradição \\
\hline Weber & Razão & \\
\hline
\end{tabular}

Tabela 1: adaptado de Halfacree - 1993.

Em sua visão sobre o tema Halfacree propõe que o problema teórico acerca da distinção entre urbano e rural origina-se de um fracasso em entender o rural como um tipo distinto de localidade e representação social. O rural como espaço e como representação do espaço confunde-se, dentre outros motivos, pela dificuldade de conceituar espaço. O espaço não tem nenhum poder causal por meio do qual possa dar origem a práticas sociais assim como não pode ser reduzido à soma de relações entre objetos. Ao considerar o espaço (e o espaço rural) nós não só temos que considerar as estruturas que o produzem mas também o modo pelo qual aquele espaço a usa para produzir outro espaço subseqüente e, fundamentalmente, reproduzir as estruturas causais originadas dele. Entretanto, de forma geral as estruturas espaciais não são suficientes para distinguir áreas urbanas de áreas rurais. A chave da questão está no desenvolvimento desigual que pode acontecer de varias maneiras em uma escala espacial. Fundamentalmente a separação rural-urbana está sedimentada na divisão do trabalho. A importância do espaço abstrato diminui comparado com a qualidade e o custo do trabalho em diferentes lugares. Em muitas circunstâncias, como no trabalho e no lazer, o espaço criado pelo rural transcende a divisão rural-urbana. Isso porque a dimensão espacial dos processos transcende a divisão rural-urbana. 


\section{2 - A necessidade de múltiplos métodos}

Em seu estudo Madsen e Adriansen (2004) sugerem que a forma para entender o espaço rural se daria a partir da combinação de dados quantitativos e qualitativos. Acreditam que por ser um desafio complexo aos pesquisadores poucos trabalhos lidam explicitamente com as implicações filosóficas e metodológicas da pesquisa baseada em uma combinação de diferentes dados e métodos.

Nas duas últimas décadas geógrafos interessados no rural foram influenciados por diferentes teorias e discursos, destacando-se o behaviorismo, a análise de sistemas, a economia política, as redes de atores e o pós-estruturalismo. Destaque-se nesse grupo a economia política: "political economy has become the dominant discourse to the extent that, for many, it has come to represent agricultural geography" (Morris e Evans ${ }^{2}$ citados por Madsen \& Adriansen, 2004).

Este desenvolvimento trouxe novos conhecimentos e interesses assim como também novas estratégias de pesquisa e métodos. Madsen e Adriansen destacam as relações entre práticas e valores dos atores rurais. Para eles "práticas" são as ações relacionadas ao uso da terra pelos atores individuais e "valores" são os pensamentos e convicções focalizados no ator individual, incluindo preferências e motivações. Entretanto as pesquisas que objetivam definir espaço rural tem dado ênfase muito grande ao ecossistema, relegando o ator individual a um segundo plano. Essa ênfase ecossistêmica possui ao menos quatro deficiências:

1. uma obsessão no estudo do aquecimento global,

2. a ignorância de fatores históricos,

3. a negligência do papel dos indivíduos e

4. problemas na definição do limite (Moran ${ }^{3}$ citado por Madsen \& Adriansen, 2004).

Essas deficiências ocorrem possivelmente devido a uma filosofia positivista aplicada no estudo dos ecossistemas. Nos últimos anos, contudo, surgiu a teoria sobre as redes de atores que vem a ser o estudo dos acoplamentos entre todas as unidades envolvidas.

\footnotetext{
2 MORRIS, C, EVANS, N. J.; 1999. Research on the geography of agricultural change: redundant or revitalized? Area: Vol. 31, Issue 4, Page 349-358, December.

${ }^{3}$ MORAN, E. F. 1990. Ecosystem ecology in biology and anthropology: a critical assessment. In: Moran, E. F. (ED.), The ecosystem Approach in Anthropology: from concept to practice. The University of Michigan Press, USA, PP.3-40.
} 
uso dessa teoria possibilita a análise da composição das redes e de que forma elas ganham força. Os atores rurais fazem parte de redes complexas que incluem consultores, planejadores, fornecedores de crédito, etc. É pela análise desses processos de mediação e transformação que devemos estudar as práticas e os valores desses atores individuais do meio rural.

\section{3 - Novas ruralidades, novas paisagens, novos significados}

O artigo de Paquete e Domon (2003) dedica-se à tentativa de entender as mudanças no espaço e na paisagem rural. Está-se atualmente diante de um paradoxo já que várias áreas rurais sofrem significativo crescimento demográfico, contrariando 0 apregoado declínio da população rural. Existe, no campo, uma dissociação entre as trajetórias sócio-demográficas e a agricultura. Várias são as visões anteriores acerca dessa mudança:

"Productivist to post-productivist (Halfacree and Coyle, 1998), industrial to postindustrial (Jollivet, 1997) or even rural to post-rural (Murdoch and Pratt, 1993) are some of many visions of the functional changes taking place within the countryside" (Paquette \& Domon, 2003).

Muitas dessas transformações estão associadas à maior influência do meio urbano e dos interesses daqueles que podem ser definidos como não-rurais. Por exemplo: a migração de contingentes populacionais urbanos para áreas rurais aumenta a demanda por novas atividades e serviços (pedreiros, domesticas, restaurantes, etc). A coexistência dessas diferentes experiências rurais refletem no crescimento das interações humanas dentro dos espaços rurais. Como resultado disso a palavra rural passa a ter múltiplos significados (de acordo com os parâmetros de cada observador) e a paisagem rural passa a ser entendida como: "a tangible imprint continuously reshaped by changing social representations of the space" (p.426). Definição essa derivada da noção de "empreinte-matrice " desenvolvida em 1990 por Berque ${ }^{5}$, isto é, são os resultados da interferência humana dentro de um determinado ambiente e também designam a interpretação e percepção daquele ambiente. Deste modo o estudo das impressões e percepções revelam aspirações coletivas ou individuais mais

\footnotetext{
${ }^{4}$ Este conceito deriva de uma idéia por meio da qual as pessoas representam ou percebem um determinado ambiente

${ }^{5}$ BERQUE, A., 1990. Médiances, de milieux en paysages. Reclus, Montpellier.
} 
verdadeiras e não meramente fatos neutros. Em suma: as distintas paisagens rurais são amoldadas através das práticas cotidianas que experimentam os residentes rurais. No entanto, dado o significativo repovoamento de algumas áreas rurais, é compreensível que experiências contemporâneas de rural sejam crescentemente influenciadas por de pontos de vista externos. Em contrapartida, até algumas décadas atrás o rural era caracterizado por longas e duráveis relações vinculadas à terra. Atualmente quando o rural é colonizado tendo por base necessidades residenciais ou 0 cultivo agrícola, isso é indicativo de identidades rurais específicas. Um urbano que compra uma propriedade rural em função da circunvizinhança também representa uma manifestação distinta dos valores locais.

Em lugar de pintar um retrato estático destas práticas e usos, o trabalho de Paquete e Domon enfatiza a natureza envolvida. Por via desta ênfase procuram mostrar evidências da diversidade e da dinâmica das paisagens, ou, como preferem, das trajetórias da paisagem.

\section{4 - Novos territórios rurais}

O trabalho sobre regulação e diferenciação dos espaços rurais de Terry Marsden (1998) toma por base a diferenciação do campo como a principal característica das mudanças no espaço rural, e explora algumas das esferas de desenvolvimento que estão influenciando esse processo de diferenciação.

Marsden, levando em conta a diferenciação dos espaços rurais, acredita que podem ser identificadas pelo menos quatro esferas chaves associadas ao desenvolvimento do rural: 1) mercados de comida em massa, 2) mercados de comida de qualidade, 3) mudanças relacionadas à agricultura e 4) reestruturação do rural que implicam, em suas diferentes combinações, em diferentes espaços rurais.

Sobre o mercado de comida em massa a maioria dos fazendeiros são levados a se vergar às grandes cadeias alimentícias dominadas pelo poder dos varejistas incorporados. Estas interações e relações são de caráter nacional e global estando sujeitas a mudanças tecnológicas que exigem maior intensidade de produção e economias de escala. Acrescente-se a isso inovações como a manipulação genética somando-se à maior influência de setores externos procurando moldar horários e técnicas industriais à natureza da produção agrícola. A questão é: até que ponto os 
produtores agrícolas podem resistir e desenvolver estratégias agrícolas substitutas para suprir essas novas demanda?

Quanto ao mercado de comida de qualidade, são grandemente diferenciados devido a uma enorme variedade de motivos normalmente associados com as condições variáveis de consumidores e uma gama de critérios socialmente construídos. Tudo isso é reforçado pela intensa competição entre corporações varejistas que estão desenvolvendo novas estratégias de mercado que refletem características locais de diferentes grupos consumidores. Novas áreas rurais são passíveis de serem incorporadas aos mercados de comida de qualidade que, no entanto, ficarão muito mais dependentes de outros padrões e convenções de produção. Por fim o produtor tradicional será incorporado, provocando novos usos de terra, criando novos espaços rurais e interferindo na diferenciação territorial.

Em uma terceira esfera de desenvolvimento encontram-se as mudanças relacionadas à agricultura. Elas estão ligadas aos resultados da atual diversificação agrícola e a seus diferentes graus de sucesso, estando baseadas em novos atores e nas inter-relações regionais e nacionais forjadas entre a unidade produtora e as redes geográficas mais largas. Estas esferas de desenvolvimento possuem localização específica e se relacionam ao crescimento particular de mercados não-locais e não-agrícolas. Existe também uma tendência de realçar a autenticidade do rural pela recriação de simulacros, expondo-os a um novo grupo de usuários e a uma nova estratégia de marketing. Essa ressignificação do rural, em longo prazo, contribuirá para a sua urbanização e transformação em commodities.

Como quarta e última esfera de desenvolvimento encontra-se a reestruturação do rural, ou o surgimento do rural não-agrícola. Em muitos espaços rurais as formas principais de desenvolvimento têm pouco para ver com a esfera agrícola. Comumente estão relacionados a atividades extra-agrícolas que visam sua exploração como a extração mineral, o turismo, o deposito de materiais tóxicos ou os loteamentos (ou condomínios para a classe média). O rural possui poucos mecanismos de defesa, sendo vulnerável a investidores externos que tentam explorar os recursos físicos e sociais de seu espaço. Esses processos de reestruturação do rural são altamente influenciados pela variedade de instituições, pelas estruturas reguladoras e pelos processos desenvolvidos em diferentes espaços rurais. 


\section{5 - Modernismo, pós-modernismo e o "pós-rural"}

O texto de Murdoch \& Pratt (1993) focaliza a produção de conhecimentos sobre a diferenciação rural-urbana em diversos estudos acadêmicos que propõe visões tidas como modernistas e pós-modernista. Alguns autores ${ }^{6}$ entendem que os termos modernismo e pós-modernismo podem ser caracterizados como um movimento cultural dentro de um período histórico particular. O modernismo aparece nos séculos XIX e $\mathrm{XX}$, associado aos trabalhos de Joyce, Yeats, Picasso, Matisse e outros. O termo pósmodernismo ganha maior ressonância cultural durante a década de 60 com Sontag, Cage e Burroughs. Mais recentemente o pós-modernismo surge principalmente nos debates sobre os trabalhos de arquitetos como Robert Venturi em contraponto aos trabalhos de modernistas como Le Corbusier e Mies van der Rohe. Em seu estudo Murdoch \& Pratt não se interessam em adotar os termos modernidade/pósmodernidade como um movimento cultural ou uma expressão da organização econômica. Para eles os termos significam uma forma de percepção do mundo que é interesse maior das ciências sociais (em particular da teoria social) e está relacionado principalmente à produção e à natureza do conhecimento. Crêem ainda que a chave para o entendimento da pós-modernidade está no livro Intimations of Postmodernity de Sygmunt Bauman ${ }^{7}$

Para Baumam (citado por Murdoch \& Pratt, 1993) as origens da modernidade estão no "entrincheiramento" do Estado absolutista moderno, conduzida por uma crise nos veículos tradicionais de controle social. Este Estado-controlador incentivou uma uniformidade supracomunal tendo a universalidade como um ideal e um parâmetro para a melhoria social. A diversidade era vista como um fenômeno transitório a caminho de um modo de vida verdadeiro e universal. Já a pós-modernidade não se constitui em uma súbita fratura da modernidade, mas representa uma volta para si mesma, ou seja, a modernidade passa a tomar consciência de sua verdadeira natureza. Há ai uma ironia: o que caracteriza a pós-modernidade - pluralismo, multiplicidade, incerteza, etc - foram vistas pelo projeto modernista como sinais de fracasso.

\footnotetext{
${ }^{6}$ FEATHERSTONE, M. 1991. Consume culture and post-modernism. Sage: London. JENCKS, C. 1987. The language of postmodern architecture $\left(5^{\text {th }}\right.$ Edn). Academy editions: London. JAMESON, F. 1984. Postmodernism, or the cultural logic of late capitalism. New left review 146, 52-92. HARVEY, D. 1989. The condition of postmodernist. Blackwell, Oxford.

${ }^{7}$ BAUMAN, Sygmunt. 1992. Intimations of Postmodernity. Routledge: London.
} 
rural e o urbano não estariam necessariamente ligados a lugares específicos. Murdoch \& Pratt (idem) entendem que esta é uma expressão em constante construção sendo que há uma luta contínua para redefinir suas relações sociais. Crêem que a sociologia do pós-modernismo ofereceria uma perspectiva mais reflexiva para seu estudo e concluem seu trabalho propondo o fim do uso de conceitos universais ou globais como rural (ou mesmo urbano) passando-se a pensar em lugares.

\section{6 - Paisagem rural: processos e estratégias}

Os estudos da evolução das paisagens rurais são ferramentas úteis para decifrar suas construções e o entendimento de espaço rural. Acerca disto destacam-se dois estudos: os artigos de Palang et al, "Rural landscapes: past processes and future strategies" (2005) e de Paul Claval, "Reading the rural landscapes" (2005).

\subsection{1 - A evolução das paisagens rurais}

O artigo de Palang et al (2005)procura demonstrar a importância da pesquisa da paisagem para a vida das pessoas. Inicialmente os autores destacam alguns temas tratados na $20^{-}$Permanent Conference for the Study of the Rural Landscapes, realizada nas cidades de Tartu e Otepää, Estónia, em agosto de 2002. A conferência concentrou seus trabalhos no passado objetivando entender como antigas mudanças na paisagem podem ser a base para suas futuras mudanças. Foram apresentados estudos acerca da: dinâmica de paisagens, das conseqüências de sua alteração, de como expressam (linguagem) aqueles que estão envolvidos na paisagem e qual é o papel da natureza sobre a paisagem rural.

Para os autores, cada vez mais é sabido que as paisagens são de grande importância para a qualidade de vida dos cidadãos. Elas não só formam o ambiente principal e portador de vida, agricultura, natureza e turismo, mas também é um elemento extremamente importante da identidade nacional, regional e local. Para o desenvolvimento das atuais e futuras paisagens culturais européias são necessárias estratégias transdisciplinares que precisam ser desenvolvidas em íntima cooperação entre pesquisas científicas e políticas públicas. Entretanto não é muito conhecido como europeus percebem e avaliam suas paisagens tradicionais. 
Essas paisagens não são apenas uma realidade física, mas também mental, social e cultural. É um importante fator que une natureza e homens tendo orientado pesquisas científicas sobre as relações mútuas entre pessoas e paisagens: grupos sociais não só influenciam paisagens, mas também são influenciados por elas.

Vários são os processos naturais e culturais que interagem na dinâmica das paisagens. Porém, na visão dos autores, o ser humano e as ciências naturais, assim como também as artes, ainda precisam ser integradas em uma disciplina holística, que seria a única capaz de alcançar uma inter ou trans-disciplinar cooperação, sendo eficaz tanto dentro da academia como entre a ciência e sociedade.

Polang et al fazem um levantamento dos principais trabalhos publicados na $20^{\mathrm{a}}$ "Permanent conference for the study of the rural landscape".

M. Antrop ${ }^{8}$ afirma que o estudo do passado das paisagens pode ser importante para seu futuro. Ele distingue três importantes períodos para o desenvolvimento das paisagens: as paisagens tradicionais após as importantes mudanças do início do século 18, as paisagens do período das revoluções dos séculos 19 e 20, e a nova paisagem pós-moderna. Acessibilidade, urbanização, globalização e calamidades são as principais forças motrizes por trás das mudanças nas paisagens, apesar de 0 efeito combinado destes quatro elementos serem diferentes no tempo e na forma como afetam a natureza bem como a avaliação humana da paisagem.

O trabalho de Hedin ${ }^{9}$ é um estudo sobre a tentativa de restabelecer uma antiga paisagem na Estônia onde as terras estão sendo restituídas aos antigos donos depois do colapso do sistema comunista. Em sua área de estudo a população é formada por suecos, fugitivos da Suécia em 1944, que reclamam o retorno às terras pertencentes a seus ancestrais. Acontece que eles não estão preparados para se instalar nas suas antigas fazendas, nem dar continuidade a práticas agrícolas. Assuntos de caráter moral e direito à continuidade emergem como preocupações principais neste processo tentando responder a indagações como: de quem são as paisagens, qual é seu futuro? Skowreonek et $\mathrm{al}^{10}$ mostram como aldeias vizinhas na Polônia, apesar de terem tido um passado semelhante, escolheram opções diferentes de futuro. A escolha é ditada

\footnotetext{
${ }^{8}$ ANTROP, M. 2005. Why landscapes of the past are important for the landscapes of the future. Landsc. Urban Plan. 70, 21-34.

${ }^{9}$ HEDIN, S. 2005. Land restitution in the former Swedish settlement areas in Estonia. Consequences for land ownership, land use and landscape. Landsc. Urban Plan. 70, 35-444.

${ }^{10}$ SKIWRONEK, E., KRUKOWSKA, R., SWIECA, A., TUCKI, A 2005. The evolution of rural landscapes in mid-eastern Poland as exemplified by selected villages. Landsc. Urban Plan. 70, 97-109.
} 
não apenas pelas diferenças nos valores atuais, mas também pelas diferentes populações e pelos padrões de reforma agrária.

Nikodemus et $\mathrm{al}^{11}$ mostra como o passado se reflete na atual estrutura da paisagem no planalto de Vidzeme, norte da Letônia. Esta é um das poucas áreas da Europa onde as camadas da paisagem são facilmente distinguíveis.

Por fim Terkenli ${ }^{12}$ discute as novas espacialidades da paisagem, causadas pelas aceleradas mudanças em nível local. Talvez a variável mais significante nesta nova espacialidade da paisagem seja a conectividade geográfica. A paisagem já não pode ser vista como mais um segmento do mundo geográfico - real, percebível ou imaginário - mas como uma imagem ou um sistema de interfaces com diferentes escalas de contato com o observador. Não raramente a paisagem tem aparecido de forma fechada, restrita, amarrada ao lugar. Função, simbolismo, processos, formas e relações com o exterior, em lugar do interior, são novas referências que crescentemente caracterizam a paisagem.

\subsection{2 - A linguagem das paisagens rurais}

O artigo de Paul Claval (2005) faz uma discussão sobre as linguagens da paisagem rural. Para Claval essas linguagens podem ser classificadas de acordo com a posição de cada grupo. Primeiro há as linguagens que possuem uma função, as gramáticas geradoras de elementos de paisagem e as semióticas de significado religioso para grupos de agricultores tradicionais. Segundo há a retórica de harmonia, pureza e status social, além do poder da classe média urbana. Finalmente, há as linguagens da natureza genuína, amenidades e atividades ao ar livre para a nova população rural resultantes das revoluções do século 20.

P. Claval afirma que nos estudos de paisagens rurais que os geógrafos começaram a desenvolver no fim de 19 século, eles usaram ou uma aproximação estrutural (cada tipo de paisagem rural tinha sido amoldado por um grupo étnico particular desde o princípio da história), uma funcional (cada paisagem rural era organizada de maneira a combinar cultivo e criação de gado de forma a assegurar uma boa colheita), ou um

\footnotetext{
${ }^{11}$ NIKIDEMUS, O., BELL, S., GRINE, I., LIEPINS, I. 2005. Impact of economic, social and political factors on the landscape structure of the Vidzeme Uplands in Latvia. Landsc. Urban Plan. 70, 69-83.

12 TERKENLI, T.H.S., 2005. New landscape spatialities: the changing scales of function and symbolism. Landsc. Urban Plan. 70, 165-176.
} 
arqueológico (as características observadas nasceram no passado e refletiram as condições funcionais que prevaleciam naquele momento). Isso significou que aquelas paisagens rurais eram organizadas de acordo com regras. Eles obedeciam a certas bases elementares (gramáticas). Até mesmo se os geógrafos não recorressem a estudos lingüísticos, as suas aproximações estavam, de certo modo, perto dos resultados da lingüística estrutural do seu tempo. Entretanto os geógrafos não tiraram proveito das evidências que eles colecionaram dentro da investigação. Jogaram fora os aspectos subjetivos dos testemunhos que tinham juntado, selecionando só a coerência dos sistemas de paisagem e as análises que tinham elaborado; sendo que seu único objetivo era entender esses sistemas. Essa dimensão funcional era certamente essencial, mas não impedia outras leituras das paisagens por parte das pessoas do lugar, como por exemplo, os símbolos.

Um segundo momento do estudo das paisagens rurais acontece nos anos 60 e 70 . Geógrafos buscam descobrir as aspirações e os modelos artísticos usados pelos arquitetos e paisagistas responsáveis por desenhar as vilas, mansões ou castelos dos prósperos proprietários de terras. A linguagem diz como a paisagem é bonita e harmoniosa. Ela também carrega um conteúdo ideológico. Deve assim ser interpretada igual a outras formas de narrativas. Neste tipo de interpretação, os geógrafos tendem a confiar na semiologia, especialmente em sua forma topológica.

Também nesse segundo momento a produtividade agrícola deu grande salto. Em conseqüência disso houve um dramático declínio na disponibilidade de emprego no campo, com duas possíveis conseqüências: ou um declínio dramático da densidade nas áreas rurais, ou uma reversão completa na composição de suas populações. Essa mudança demográfica provocou importantes conseqüências na composição da paisagem rural. A lógica funcional da rotação de culturas e a associação entre agricultura e pecuária deixaram de reger a maioria dos territórios. A nova população rural deixou de compartilhar os românticos sonhos dos proprietários de terras. Acreditavam que agricultura tradicional era uma atividade pouco nobre. Esses novos rurais estão apaixonados pela verdadeira natureza e ao se instalarem em uma área rural surgem possibilidades para praticar esportes, jogos e qualquer outro tipo de atividade ao ar livre.

Para Claval (idem) os estudos das paisagens rurais tradicionais podem ser feitos de acordo com três perspectivas: 
1. como um conjunto de campos, prados, pastagens e matas que se organizaram para produção agrícola;

2. como expressões das sociedades que os habitam;

3. como uma superfície onde pode se ler a natureza e descobrir a existência de outros mundos.

Ao explorar o agrário, os processos que eram responsáveis pela gênese de paisagens passaram a ser resultado de ações planejadas.

Paul Claval faz ainda uma análise da paisagem rural em tempos de pós-modernidade, com novos tipos de atividades e uma nova composição social presentes nas áreas rurais.

Para ele, na era pós-moderna, o rural perdeu seu caráter amigável e amador. Tornouse uma atividade altamente industrial e muitos fazendeiros tiveram que se especializar em fazendas abertas para novos objetivos. Áreas rurais contemporâneas deixaram de evocar as pastagens, rebanhos e agricultores arcaicos. A agricultura deixou de ser modelo para os sonhos de moradores urbanos. Sociedades pós-modernas quebraram definitivamente as ligações com a civilização rural clássica. A percepção das pessoas acerca das áreas rurais tem sofrido mudanças por outras razões. Até uma geração atrás, o contraste entre áreas agrícolas e a selva não parecia muito nítido. $O$ agricultor estava envolvido em uma diferente forma de natureza, com a criação de campos cultivados e pastagens que substituíam, em parte, as matas e os campos naturais. Então, cultivar não era considerado como uma ameaça à natureza.

A modernização trouxe conseqüências profundas: campos ou pastos foram ficando cada vez mais semelhantes a laboratórios químicos para fertilizantes e pesticidas. Criar vacas, ovelha e porcos se tornou uma atividade científica. O ambiente agrícola se tornou artificial debaixo de um completo controle humano Sua administração arrisca o equilíbrio natural: terras e água são poluídas por overdoses de fertilizantes e pesticidas e que causam sua eutrofização. A fratura com o tradicional e o novo estilo de agricultura conduziu a uma nova concepção de natureza: ela só existe onde não há nenhuma atividade humana. Acontece que todo mundo sabe que os parques e reservas naturais só subsistirão com uma administração humana muito cuidadosa.

A conclusão a que chega P. Claval é: a paisagem é o resultado das atividades e dos interesses humanos sendo que suas formas de interpretação e suas linguagens não são universais. Ele propõe uma classificação das linguagens da paisagem rural 
baseadas na posição econômica, social, e cultural dos grupos que eram ou são responsável por sua gênese:

1. as funções dos idiomas, as gramáticas geradoras de elementos da paisagem e as semióticas de significado religioso, para grupos tradicionais;

2. a retórica de harmonia e pureza de estado social que dá poder superior para urbanos de meia-idade da classe média;

3. as linguagens de natureza genuína, amenidades e atividades ao ar livre para a nova população rural resultante das revoluções do século 20 .

Modelos lingüísticos são úteis para geógrafos que tentam decifrar e interpretar formas específicas de paisagens rurais. Eles podem encontrar: a evolução da dialética, a definição da própria zona rural; os modelos de lingüísticas estruturais e gramáticas geradas pelas formas clássicas de paisagens agrárias; semióticas para as leituras estéticas e sociais que eram tão importantes nos campos religiosos de sociedades puramente rurais, ou no ideológico para sociedades urbanas modernas.

\section{3 - Para além do agrícola}

Diante do crescente domínio dos espaços urbanos e do acelerado crescimento das cidades parece natural pensar que o rural deixou ou deixará de existir como categoria distinta.

"É possível afirmar que a humanidade caminha em direção a um mundo de urbanização geral [...] porque áreas rurais tenderão a formar parte dos sistemas de relações econômicas, políticas, culturais e de comunicação organizadas a partir dos centros urbanos" (Luz, 2003).

Mas também é crível pensar o rural não mais como sinônimo de agrícola ou de atraso mas como espaço distinto/distinguível de uma estrutura geográfico-social maior. Haveria uma nova ruralidade.

O conceito de ruralidade perdeu, nos dias atuais, qualquer vestígio de homogeneidade enquanto classe analítica. Não pode ser entendida como um oposto do urbano ou como território da agricultura. Mesmo culturalmente não há mais unidade ou um conjunto. Seria uma evolução, não no sentido de desenvolvimento tecnológico mas na 
forma de ser percebido. Para exemplificar isso é plausível fazer uma analogia à obra de Pablo Picasso.

O rural não mais deve ser tomado como as primeiras obras de Picasso. No quadro "Ciência e Caridade" (llustração 1) os espaços eram claros, delimitados e finitos. Não havia a necessidade da busca já que a interpretação de dava de forma direta, axiomática. Cada peça, cada construção, estava em seu devido lugar. Modernamente ele se transforma num espaço que se insinua, se subdivide, se sobrepõe. Como a colagem "Guitarra" (Ilustração 2) que serviu como uma ruptura de Picasso com seu passado. O espaço rural moderno rompeu com seu passado, mas não o negou.

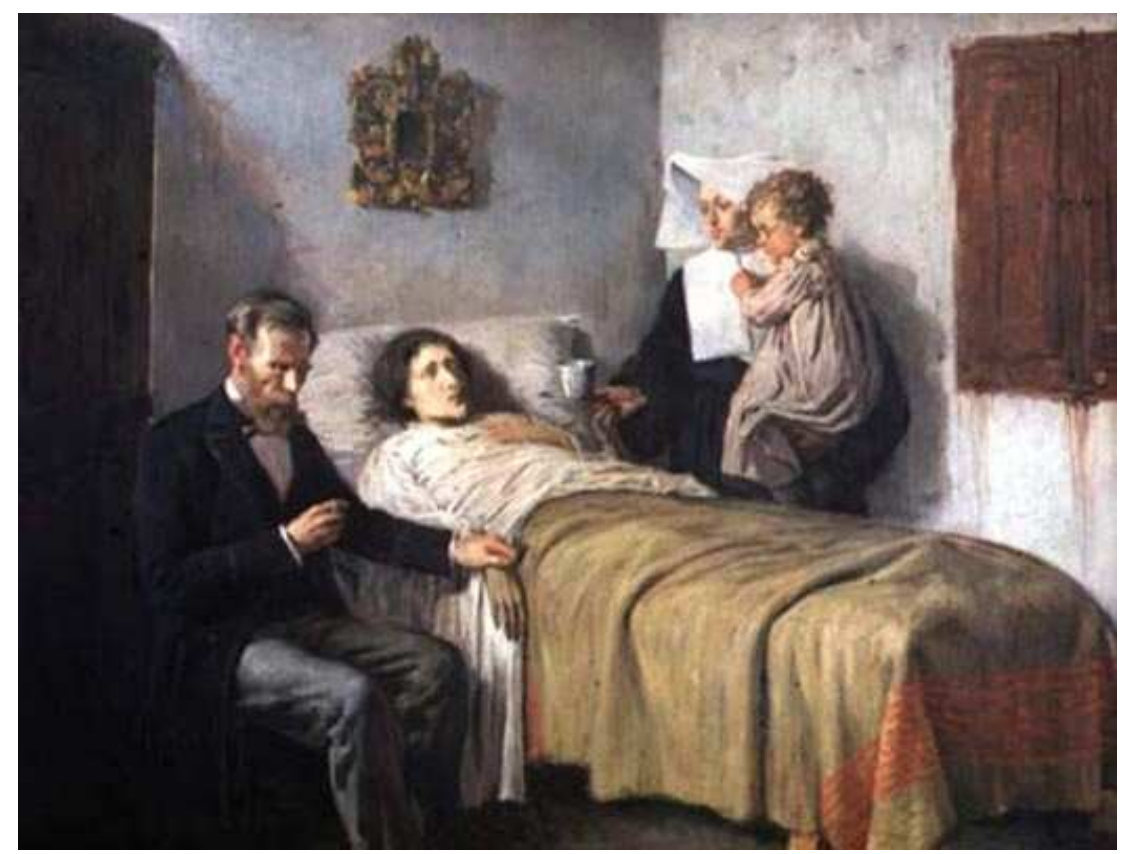

llustração 1: Ciência e caridade (Pablo Picasso, 1897) 


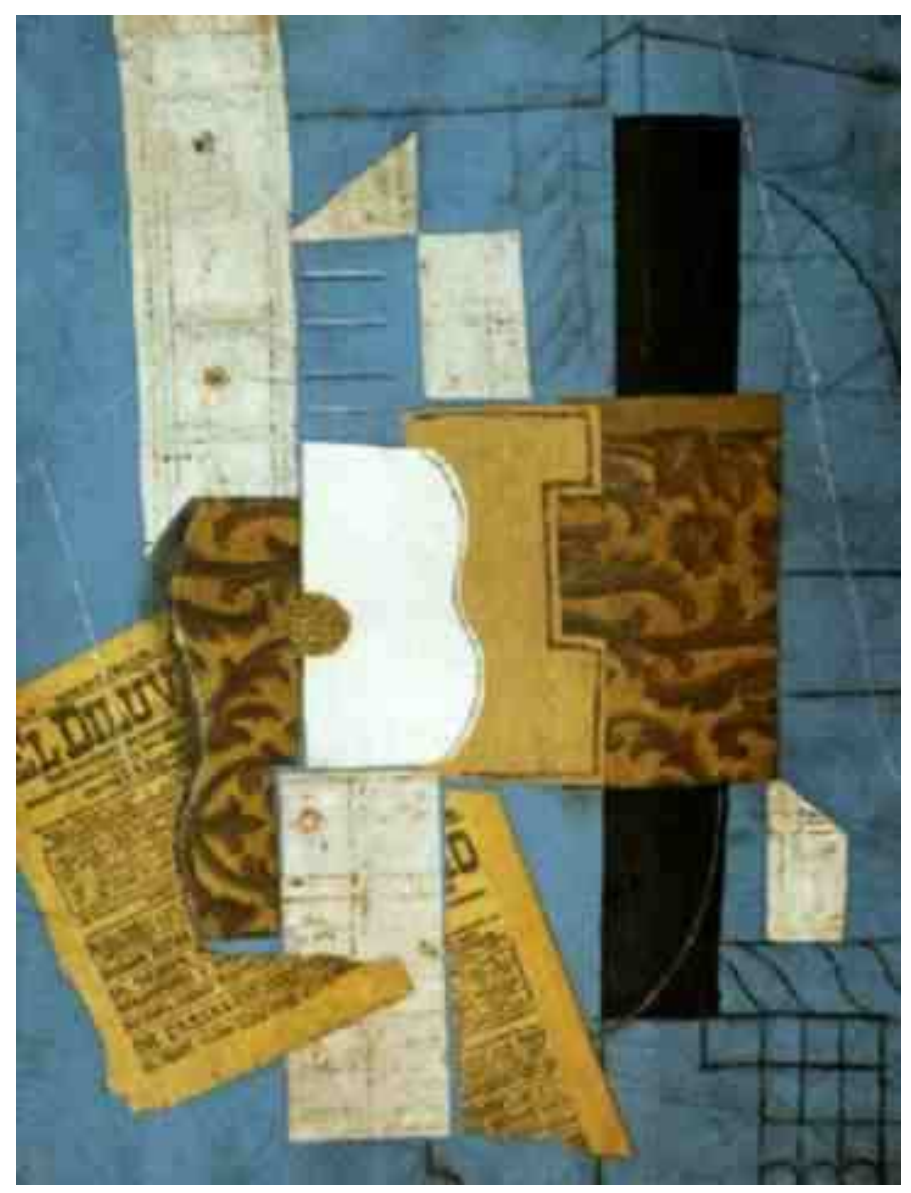

Ilustração 2: Guitarra (Colagem, Pablo Picasso, 1912).

Hoje temos as festas que de origem tipicamente rural (como as Juninas, ou a música sertaneja) que são manifestações corriqueiras dos espaços urbanos. Mesmo a divisão do trabalho entre campo e cidade já não é suficiente para conceituar uma ruralidade, apesar dessa divisão, de acordo com Saraceno, não ter sido verdadeira "sequer para o período pré-industrial no qual a população é predominantemente camponesa e desenvolve também todas as atividades de manufatura e serviços necessários à sua reprodução localmente" (1996).

Do ponto de vista socioeconômico rural brasileiro vive um processo de retração do emprego agrícola e incremento de atividades não agrícolas. De 1992 a 1995 houve um decréscimo da população rural ocupada em atividades agrícolas da ordem de 2,2\% e um crescimento da população rural ocupada com atividades não-agrícolas da ordem de 3,5\% ao ano. (Silva, 2002).

"Esse processo de ocupação do espaço rural com outras atividades que não a agricultura-pecuária ganha relevância em um contexto onde a aceleração do ritmo de 
vida urbano, em condições de crescente depreciação da qualidade de vida, tem atribuído ao campo uma dimensão de ambiente de revigoramento das relações entre indivíduo e natureza, com o culto das formas ecológicas e das raízes culturais das comunidades rurais. Diante disso, tais atividades têm se firmado como alternativa de ocupação e renda no meio rural" (Martins, 2005).

Em grande parte dos trabalhos acadêmicos publicados por estudiosos brasileiros nos últimos anos percebe-se a aceitação de uma espécie de espaço rural hibrido ou um espaço "meio-termo" entre o urbano e o rural. É dada ênfase à cultura, ao turismo rural, às questões ambientais e às novas tecnologias disponíveis como fatores caracterizantes/descaracterizantes do espaço rural.

Para José Graziano da Silva, a diferenciação rural/urbana teve, historicamente, dois momentos marcantes: a separação do campo e da cidade quando a indústria se muda para a cidade e o movimento inverso de reunificação quando a agricultura "converte-se num ramo da própria indústria" (Silva, 1981). Atualmente haveria uma verdadeira subordinação da agricultura (ou da natureza) ao capital fazendo com que a produção agropecuária transforme-se em mais uma força sob seu domínio. Como exemplo desse fenômeno temos os complexos agroindustriais, que se solidificam no Brasil a partir dos anos 60, exigindo dos seus partícipes ou integrados a implementação de técnicas produtivas típicas do setor industrial (padronização dos produtos, regularização e diminuição do tempo de produção, etc). O componente de unicidade presentes nas varias atividades dos complexos agroindustriais "é que todas elas são atividades do capital, com uma regulação macroeconômica mais geral" (Silva, 1996).

Numa trajetória pró-urbanização do rural, José Graziano da Silva mostra, já na apresentação de seu livro "o novo rural brasileiro", as quatro bases que, segundo ele, consistiria o "novo rural" brasileiro.

"(1) uma agropecuária moderna, baseada em commodities...; (2) um conjunto de atividades de subsistência que gira em torno da agricltura rudimentar e da criação de pequenos animais, que visa primordialmente maner relativa superpopulação no meio rural e um exercito de trabalhadores rurais sem terra, sem emprego fixo, sem qualificação...; (3) um conjunto de atividades não-agrícolas, ligadas à moradia, ao lazer e a várias atividades industriais e de prestação de serviços; (4) um conjunto de novas atividades agropecuárias, localizadas em nichos específicos de mercados" (Silva, 2002).

Segundo ele o que surge realmente no rural são "novas" atividades como: 


\begin{tabular}{|c|c|}
\hline Novas atividades rurais & Características \\
\hline Piscicultura & $\begin{array}{l}\text { Pesque-pagues destinados ao lazer. } \\
\text { Criação de frigoríficos com a implantação de } \\
\text { sistema de semi-integração do produtor. } \\
\text { Turismo rural (Pantanal, Amazonas e Paraná) }\end{array}$ \\
\hline Criação de aves nobres & $\begin{array}{l}\text { São aves tidas como nobres e/ou exóticas } \\
\text { (faisões, perdizes, codornas). } \\
\text { Criação de avestruz. } \\
\text { Criação de gansos, patos, galinhas de angola, } \\
\text { pavão, abelhas nativas (sic), pássaros de canto e } \\
\text { de porte). }\end{array}$ \\
\hline Criação de rãs & $\begin{array}{l}\text { Destinadas principalmente à produção de carne. } \\
\text { O Brasil é um dos maiores produtores mundiais. }\end{array}$ \\
\hline $\begin{array}{l}\text { Criação de outros animais de } \\
\text { corte }\end{array}$ & $\begin{array}{l}\text { Animais como o camarão-de-água-doce, jacarés, } \\
\text { capivaras, javalis e escargot. }\end{array}$ \\
\hline $\begin{array}{l}\text { Produção orgânica de ervas } \\
\text { medicinais }\end{array}$ & 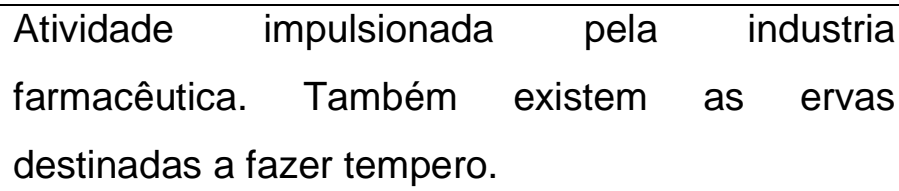 \\
\hline $\begin{array}{l}\text { Produção orgânica para } \\
\text { mercado internacional } \\
\text { diferenciado }\end{array}$ & $\begin{array}{l}\text { Produtos de custo mais elevado mas voltados } \\
\text { para um mercado internacional disposto a pagar } \\
\text { mais por ele. }\end{array}$ \\
\hline $\begin{array}{l}\text { Produção de verduras e } \\
\text { legumes para as redes de } \\
\text { supermercados e de fast-food. }\end{array}$ & $\begin{array}{l}\text { Essa produção é feita principalmente em estufas } \\
\text { ou pelo método da hidroponia. }\end{array}$ \\
\hline $\begin{array}{l}\text { Floricultura e mudas de plantas } \\
\text { ornamentais }\end{array}$ & $\begin{array}{l}\text { A cidade de Holambra, em São Paulo, tem se } \\
\text { destacado nessa atividade. }\end{array}$ \\
\hline Fruticultura de mesa & Destinada principalmente ao consumo in-natura. \\
\hline $\begin{array}{l}\text { Produção de sucos naturais e } \\
\text { polpa de fruta congelada }\end{array}$ & $\begin{array}{l}\text { Utilizando polpas de frutas regionais como } \\
\text { graviola, umbu, cajá e cupuaçu. }\end{array}$ \\
\hline $\begin{array}{l}\text { Reprodução de plantas } \\
\text { extrativas }\end{array}$ & $\begin{array}{l}\text { Neste caso o objetivo é substituir a extração de } \\
\text { plantas da natureza. O melhor exemplo é o } \\
\text { palmito. }\end{array}$ \\
\hline Cultivo de cogumelos & Os grandes centros urbanos tem demandado \\
\hline
\end{tabular}




\begin{tabular}{|l|l|}
\hline \multirow{2}{*}{ Turismo rural } & espécies como o champignon e o shiitake. \\
\hline Fazenda-hotel & $\begin{array}{l}\text { Tem se desenvolvido de forma destacada nos } \\
\text { estados de São Paulo, Paraná, Minas Gerais, } \\
\text { Goiás e Mato Grosso. }\end{array}$ \\
\hline Complexos hípicos & $\begin{array}{l}\text { Diferentemente dos hotéis-fazenda nas fazendas- } \\
\text { hotéis as atividades e rotinas continuam } \\
\text { acontecendo de forma natural. }\end{array}$ \\
\hline Leilões e exposições & $\begin{array}{l}\text { Negócios ligados ao hipismo movimentaram R\$ } \\
2,8 \text { bilhões no período de 1993-1997. }\end{array}$ \\
agropecuárias & $\begin{array}{l}\text { Leilões e exposições agropecuárias tem se } \\
\text { espalhado pelo país gerando milhões de reais em } \\
\text { negócios a cada ano. }\end{array}$ \\
\hline Festas de rodeio & $\begin{array}{l}\text { Atividade que movimentou mais de US\$ } 500 \\
\text { milhões somente em 1996 e tem crescido desde } \\
\text { então. }\end{array}$ \\
\hline
\end{tabular}

Fonte: 1 Adaptado de SILVA (2002)

Silva salienta ainda que o termo "novas" é utilizado no sentido de "atividades recriadas" já que muitas das atividades acima citadas já existiam. Também seriam novas as famílias pluriativas, isto é, aquelas que combinam atividades agrícolas e não-agrícolas. Os fundamentos dessa renovada estrutura do espaço rural estão na sua urbanização, fundamentalmente nos países desenvolvidos, que passaram por um "processo de industrialização da agricultura" e sofreram o "transbordamento do mundo urbano" (Idem). Estaria em andamento um duplo processo de urbanização do espaço rural brasileiro devido a uma expansão de uma lógica produtiva caracteristicamente urbana para os setores mais modernos da agricultura e o deslocamento de atividades também urbanas para as áreas onde a agricultura modernizada não se implantou. Essa lógica produtiva urbana e seu deslocamento para o mundo rural estaria vinculada à pluriatividade do trabalhador rural que combinaria "desde a prestação de serviços manuais até o emprego temporário nas indústrias tradicionais (agroindústrias, têxteis, vidro, bebidas, etc)" e com a "combinação de atividades tipicamente urbanas" como, por exemplo, a administração das atividades agropecuárias (ibidem).

Duas das principais conclusões a que chega Silva são de que (1) "o espaço rural não mais pode ser pensado apenas como lugar produtor de mercadorias agrárias e 
ofertador de mão-de-obra" e que (2) "a criação de empregos não-agrícolas nas zonas rurais é a única estratégia capaz de reter a população rural pobre nos seus atuais locais de moradia"(ibdem).

Ele também propõe políticas de desenvolvimento para esse novo rural, são elas: policias de "desprivatização" de espaço rural com a criação de moradias rurais, recuperação de vilas e colônias; políticas de urbanização de meio rural visando a criação de infra-estrutura de transportes e comunicações; políticas de geração de renda e ocupações não-agrícolas que visem estimular a pluriatividade das famílias rurais; políticas sócias compensatórias ativas, tais como aposentadoria precoce em áreas desfavoráveis e um reordenamento político-insituicional que reconheça as novas formas de regulação que vêm surgindo no novo rural (ibidem).

Num movimento diametralmente oposto aos postulados de Silva e daqueles que defendem o fim do rural e a hegemonia do urbano, José Eli da Veiga vem, em diversos artigos, livros e palestras, travando batalha no sentido de reafirmar que "nem tudo é urbano".

Já na introdução do livro "Cidades Imaginárias" (Campinas: Autores Associados, 2003) o autor chama a atenção para a necessidade de desfazer a indecisão ou imprecisão dominante na visão oficial sobre o desenvolvimento territorial do Brasil. Haveria uma necessidade premente de renovação do pensamento brasileiro sobre as "tendências da urbanização e de suas implicações sobre as políticas de desenvolvimento que o Brasil deve adotar" (Veiga, 2003). Para consubstanciar seu questionamento ele se baseia no fato de que o Brasil é a única nação do mundo que considera urbana toda sede de município e de distrito. Segundo ele os parâmetros da OCDE (Organização de Cooperação e de Desenvolvimento Econômico) afiançam ser necessário no mínimo uma densidade demográfica de $150 \mathrm{hab} / \mathrm{km}^{2}$ para que uma localidade seja considerada urbana. Tendo por base esse critério o Brasil passaria a ter apenas 411 municípios urbanos de um total de 5.507 .

Um dos problemas centrais dessa disparidade estaria fincada no fato de que a legislação brasileira, para definir o que é rural e o que é urbano, "encontra-se obsoleta" pois foi formulada ainda no período do Estado Novo getulista. Como base para comparação Veiga relata que existem, no mundo desenvolvido, de acordo com tipologia desenvolvida pela OCDE, três tipos de paises: 
1. os relativamente rurais,

2. os essencialmente rurais e

3. os essencialmente urbanos.

No primeiro grupo estariam, por exemplo, França e Japão, paises que possuem de $50 \%$ a $70 \%$ de seus territórios ocupados por regiões essencialmente rurais e totalmente rurais. No segundo grupo entrariam paises como os Estados Unidos e a Austrália onde mais de $70 \%$ de seus territórios são essencialmente ou totalmente rurais. Por ultimo estão aqueles países, como é o caso da Holanda, Bélgica e Reino Unido, cujas regiões essencialmente urbanas ocupam mais de $30 \%$ de seu território e as regiões essencialmente rurais não passam de $20 \%$ da suas áreas totais. Nesses países a maior parte da população vive em locais relativamente ou essencialmente rurais e as regiões rurais mais prosperas tem em seu núcleo um ou mais centros urbanos que possuem a função de pólos gravitacionais, "daí a importância de se entender que as economias locais resultam de relações sinérgicas entre atividades urbanas e rurais" (idem).

Não haveria assim uma oposição ou um continuum rural-urbano, mas uma inter-relação visto que eles estão imanamente ligados.

"Enfim, a visão de uma inelutável marcha para a urbanização como única via de desenvolvimento só pode ser considerada plausível por quem desconhece a imensa diversidade que caracteriza as relações entre espaços rurais e urbanos dos países que mais se desenvolveram. Não faz sentido, portanto, amalgamar desenvolvimento e urbanização" (Veiga, 2004).

Assim, mesmo a maior densidade demográfica das áreas que não são totalmente rurais e nem chegam a ser propriamente urbanas configura-se em fator suficiente para concluir que não existe mais "a contradição material e histórica entre o fenômeno urbano e o fenômeno rural" (Idem).

\section{4 - De espaço infinito a espaço fracionado}

Esse trabalho entende que o pequeno resgate teórico feito até aqui é inicialmente suficiente para concluir que o espaço rural permanece como um conceito passível de diferenciação e estudo, porém, de forma alguma isolado, embora passível de recorte. 
A superfície da terra é a base do espaço geográfico. Neste sentido o espaço é finito pois se fecha em si mesmo, mas é ilimitado já que nunca se chega a seu fim. O rural, assim como o urbano, podem ser vistos como dois recortes desse espaço que se engalfinham numa espécie de disputa pela superfície do planeta. No entanto jamais negam sua natureza ontológica, inerente a todos e a cada um.

Enquanto ontologia o rural não é. Não existe per si. Sua gênese está em sua representação que é, a um só tempo, inusitada e diversa. Inusitada no sentido de gerar reações singulares, pessoais e personalistas. Diversa por seu papel de representação do conjunto ou da multiplicidade. $O$ espaço rural é a diferença e a alteridade. Tendo isso como hipótese, não haveria então como falar em rural a partir de um pensamento newtoniano, onde o todo existe como um fator em si. Ele estaria ligado à compreensão do espaço relativo encontrada em Leibniz.

Gottfried W. Leibniz contrapõe a visão mecanicista de seu contemporâneo Isaac Newton. Este concebia o espaço infinito e conseqüentemente os recursos naturais também infinitos. Seu entendimento de espaço se baseava na necessidade da existência de um ponto ou quadro fixo de referência para um corpo, já que haveria uma diferença absoluta entre um corpo em repouso, em movimento e sob aceleração. Esse quadro fixo seria o espaço absoluto em relação ao qual os corpos se movem ou se aceleram. Leibniz critica tal entendimento já que, para sua existência, esse espaço teria que ser totalmente uniforme e homogêneo, não havendo então marcadores, impedindo assim sua função como quadro de referência. Leibniz conclui que o espaço é irreal ou uma abstração, sendo que a única base para verdades sobre relações espaciais era a maneira como estas se mostram a diferentes observadores (Leibniz, 1997).

Assim o espaço rural é leibniziano na medida em que ele somente se forja a partir de abstrações. A aceitação de sua existência somente se faz pelo assentimento da existência de diferentes rurais, distintas relações e múltiplos olhares.

Uma exemplificação da forma da pensar o espaço que se defende aqui pode ser feita através de uma analogia a trabalhos do impressionista Paul Cézanne. Ele pintou sessenta versões da mesma paisagem: a montanha de Sainte-Victoire.

$\mathrm{Na}$ tela abaixo (llustração 3), Cézanne mostra, de forma por vezes direta, cada elemento: as casas, as árvores, a montanha, as feições do relevo, uma vertente montanha; tudo isso representado de forma completa, quase que absoluta e com realismo suficiente para lembrar, por sua estrutura ritualística e pela clara distinção do 
fundo em relação à figura, o espaço absoluto newtoniano-euclidiano. Neste caso os elementos estão no espaço.

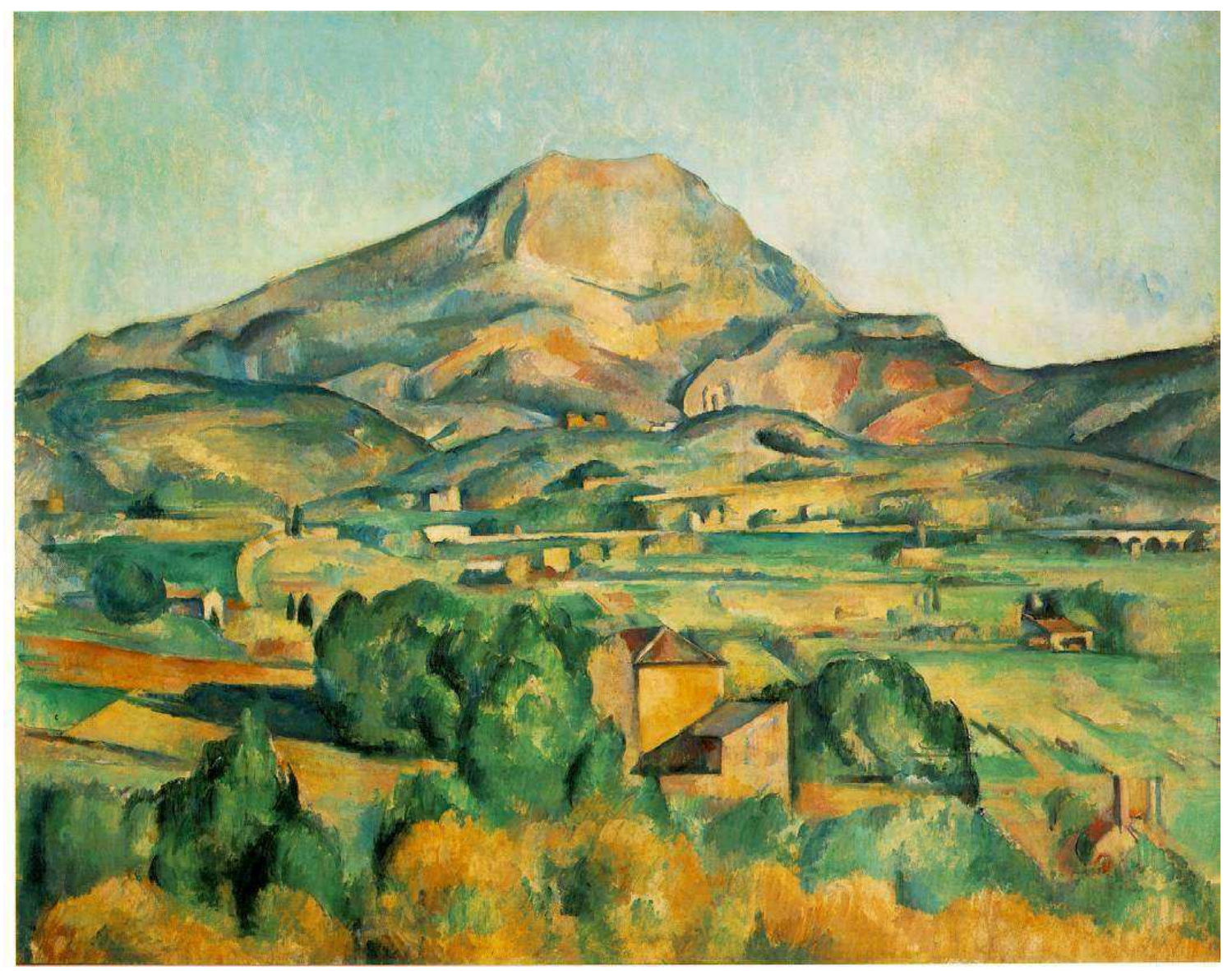

llustração 3: Paul Cézanne. A montanha Sainte-Victoire.

Mais à frente (llustração 4), Cézanne deixa o espaço transparecer o despontar de um processo simplificador onde os pormenores se confundem perante a absorção poderosa das massas. Antes precisos, delimitados e localizáveis, se tornam manchas multicores que "se acotovelam" e gravitam em torno de um eixo invisível (Campos, 2005). 


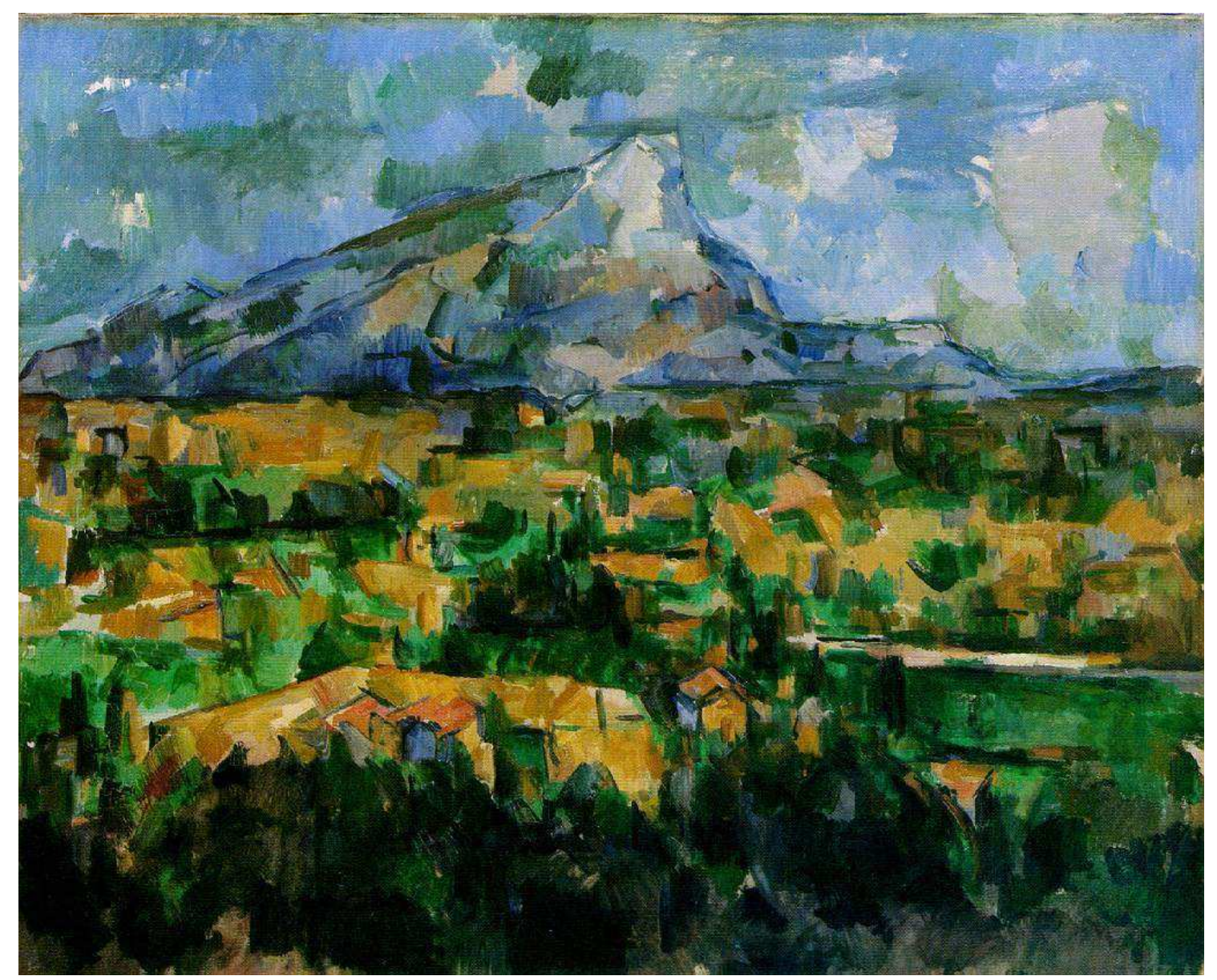

llustração 4: Paul Cézanne. Sainte-Victoire.

Em outra versão (llustração 5), Cézanne segue quase numa ambivalência destruidora/reconstrutora do espaço

"Há pontos móveis de referência topológica, traços descontínuos que se propagam, delineando uma situação semi-estilizada onde a coligação das partes fica por conta das variegadas combinações de movimentos lineares somente sintetizáveis mediante uma paciente análise óptica" (idem). 


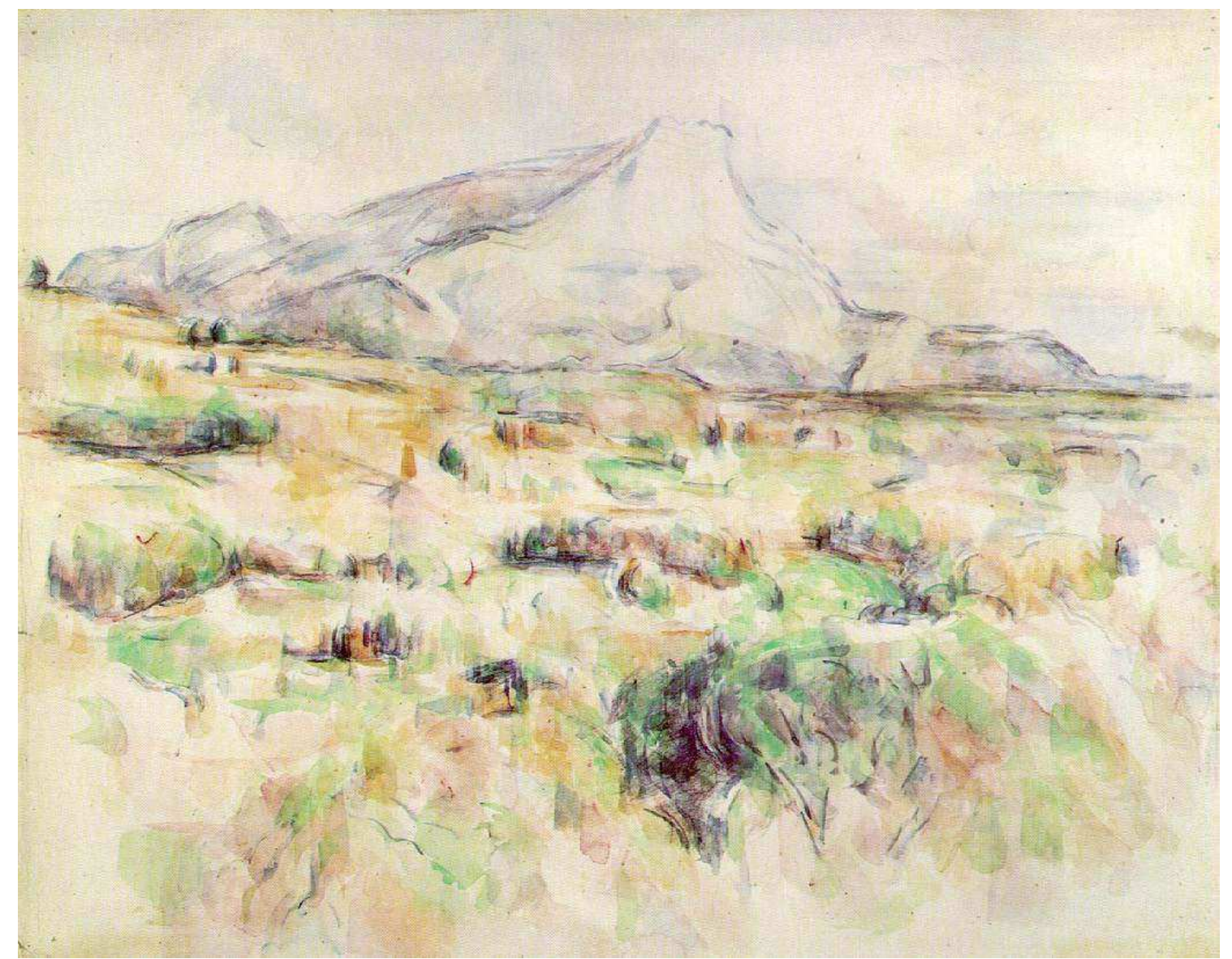

Ilustração 5: Paul Cézanne. A montanha Sainte-Victoire vista dos Lauves.

Por fim (

llustração 6), o artista, diante da mesma paisagem, mas com diferente percepção, praticamente não coloca elementos claramente discerníveis ao primeiro olhar. "Há uma ambivalência luminosa de manchas que reverberam sobre um fundo branco" (ibidem). 


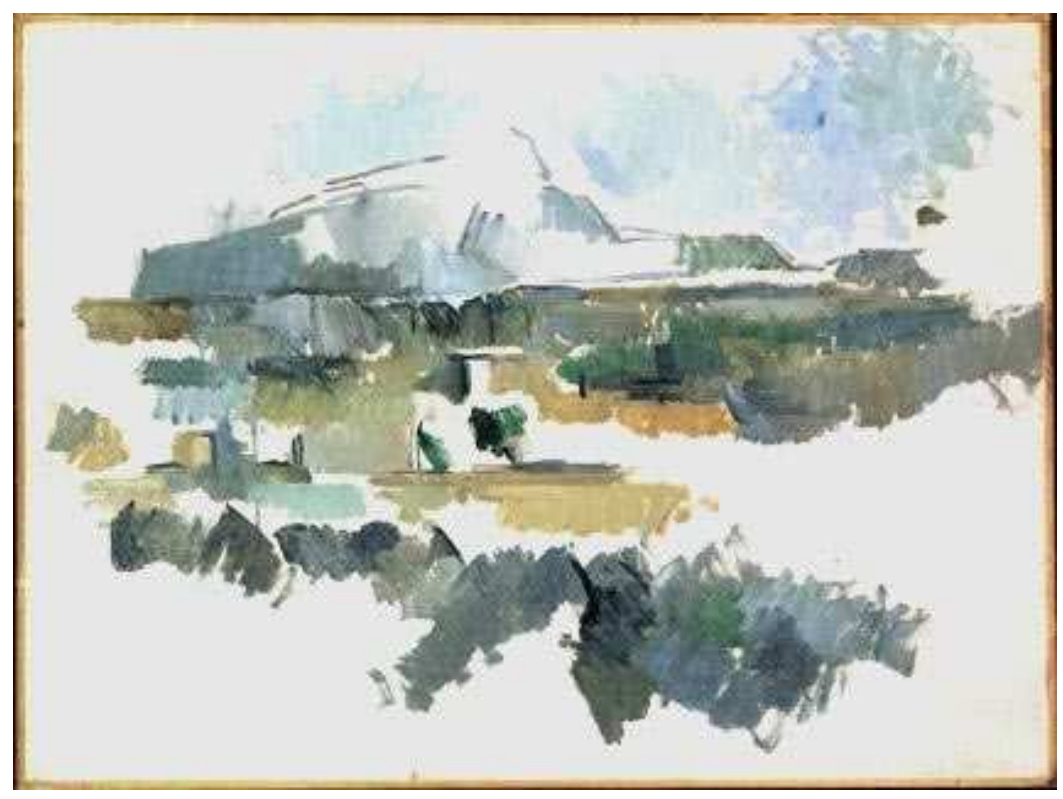

Ilustração 6: Paul Cézanne. Sainte-Victoire

A partir dessa analogia procura-se perceber o espaço rural (e seu recorte, a paisagem), como sendo imanente, ou seja, cria, determina e transforma sua própria interioridade multicultural e multidimensional. Também é o intertexto, ontológico, múltiplo e concreto. O campo, o agrário, o agrícola são fragmentos dum espaço onde o camponês, o agricultor e o empreendedor rural, são seus atores. Ele, porém, não é apenas o agrupamento desses fragmentos e desses atores. O surgimento de atividades nãoagrárias não implica, necessariamente, no surgimento de atividades típicas da urbe. Rural se liga dialeticamente à cultura, ao meio, aos fluxos, às relações e à história. É necessário repensar esse espaço dentro de uma nova concepção em que as analogias ganham relevância, as diferenças se reordenam, se reconstroem, e as estruturas se reinventam. A inserção de características culturais e tecnológicas urbanas muda o rural, embora não os tornem independentes do ambiente e da natureza a que estão inseridos. Sua população não é composta apenas por pessoas que vivem da agricultura, pecuária ou atividades ligadas ao meio-ambiente. É comum encontrar famílias onde as relações de trabalho são híbridas ou sazonais. Terão membros trabalhando na agricultura, outros em atividades nos setores terciário e secundário e ainda alguns que mesclem os dois afazeres. Também é cada vez mais utilizado como residência para aposentados e moradores que trabalham nos grandes centros urbanos. É o local de investimento para os capitais pequenos e médios urbanos que investem em empreendimentos tanto 
agrícolas como não-agrícolas (loteamentos, condomínios, etc) ou mesmo voltados para atividades como o turismo e a conservação e proteção da natureza.

A percepção e a nominação são agentes delimitadores da distinção.

Na percepção são aguçados nossos receptores sensoriais, nosso tato, audição, olfato, visão. Esses receptores não agem isoladamente em nossa mente. São eles que dão a alma, ou, noutro dizer, espiritualizam o lugar, a paisagem e o espaço. São, devido à sua ambivalência, coletivamente individuais ou individualmente coletivos. Muito do que se apreende como rural é sentido coletivamente, isto é, o espaço agrário é majoritariamente tido como rural. Mas também é individual. Uma imagem, um cheiro, um barulho podem levar ao sentimento de estar no rural. A principal distinção do rural se da através dos sentidos.

Já a nominação, como os nomes dos lugares, das vertentes, dos cursos d'água, contribuem para a caracterização do rural. As manifestações culturais muitas vezes caracterizam e distinguem um espaço. Guimarães Rosa, por exemplo, utilizou-se magistralmente das nominações e dos neologismos para, por exemplo, descrever as cores e tipos dos "gados":

Galhudos, gaiolos, estrelos, espácios, combucos, cubetos, lobunos, lompardos, caldeiros, cambraias, chamurros, churriados, corombos, cornetos, bocalvos, borralhos, chumbados, chitados, vareiros, silveiros... E os tocos da testa do mocho macheado, e as armas antigas do boi cornalão..." (Rosa, 2006).

Qualquer comunidade rural terá sempre uma estirpe própria de nomes a alcunhar os vários lugares, paisagens, acidentes geográficos, etc.

Também é fato que as modernas transformações no espaço rural se deram de forma social e territorialmente descontinua e dessemelhante. Não há mais o espaço exclusivo, ligado a atividades unívocas. O crédito agrícola, as leis, os programas de desenvolvimento rural, as manifestações culturais de origem rural, são debatidas, deliberadas, promulgadas, divulgadas e encenadas nas cidades. Se no século XIX Karl Marx chegou a afirmar que "a oposição entre a cidade e o campo começa com a transição da barbárie à civilização" (Marx, 1987), no início do século XXI o rural já não pode ser entendido como o espaço do atraso já que a modernização do campo chega, em alguns lugares, a ser mais acentuada que nas cidades (Alentejano, 2003). No entanto ele ainda se distingue pela dimensão de sua cultura, valores e representações. 
O atual espaço rural se forja em conexão com espaços urbanos e não raramente se estrutura dentro da urbe. Então o espaço rural não esta mais somente no campo, mas diversas vezes ele se sobrepõe ao espaço urbano e às cidades. Apesar disso suas relações de trabalho, suas relações sociais e suas relações culturais possuem características próprias, discerníveis, mas não necessariamente exclusivas. Características como a ligação com a terra, a forte influência da sazonalidade, os vieses culturais, a permanência de relações não capitalistas, identidade e representações especificas são marcantes no espaço rural, embora não exclusivas a ele.

O rural permanece não somente pela presença de uma ou mais dessas características, mas pela sua ontologia, sua territorialidade e seus fluxos. Assim, o espaço rural não é exclusivo, não é um continuum e nem é o oposto de nada. É um espaço próprio, conspícuo, distinguível.

\section{Bibliografia}

ALENTEJANO, Paulo R. R., As relações campo-cidade no Brasil do século XXI in Terra Livre, ano 19, v2, n.21, Associação dos geógrafos do Brasil, São Paulo, 2003, p25-39.

BERMAN, Marshall. 2005. Tudo que é sólido desmancha no ar - a aventura da modernidade. São Paulo: Companhia das Letras, 434p.

CAMPOS, Jorge Lucio de. 2005. Espéculo. Revista de estudios literarios. Universidad Complutense de Madrid. Diponivel em http://www.ucm.es/info/especulo/numero31/ francas.html em setembro de 2005.

CLAVAL, Paul. 2005. Reading the rural landscapes. UK: Landscape and urban planning, 70, p.9-19.

DOMON, Gérald; PAQUETTE, Sylvain. 2003. Changing ruralities, changing landscapes: exploring social recomposition using a multi-scale approach. UK: Journal of rural Studies, 19, p425-444.

HELFACREE, K. H.1993. Locality and social representation: space, discourse and alternative definitions of the rural. UK: Journal of Rural Studies, vol. 9, n 1, pp. 23-37.

LEIBNIZ,G.W.1997. O discurso de metafísica. Lisboa: edições 70. 
LUZ, Adilson Bastos. 2003. O urbano-rural. Salvador: conj. e planejamento, n106, p.30-34, março.

MADSEN, Lene Moller; ADRIANSEN, Hanne Kirstine. 2004. Understanding the use of rural space: the need for multi-methods. UK: Journal of Rural Studies, $v 20, p$ 485-497.

MARSDEN, Terry. 1998. New Rural Territories: Regulating the Differentiated Rural Spaces. UK: Journal of Rural Studies, v 14, n 1, pp. 107-117.

MARTINS, Rodrigo Constante. 2005. Ruralidade e regulação ambiental: notas para um debate político-institucional. Rev. Econ. Sociol. Rural, Apr./June, vol.43, no.2, p.249-266

MARX, K. 1987. A ideologia alemã. São Paulo: Hucitec,.

MURDOCH, Jonathan; PRATT, Andy C. 1993. Rural Studies: Modernism, Postmodernism and the 'Post-rural'. UK: Journal of rural Studies, v 9, n 4, pp. 411-427.

PALANG, Hannes, HELMFRID, Staffan, ANTROP, Marc, ALUMÄE, Helen; 2005. Rural landscapes: part processes and future strategies. v70, Janeiro, pp3-8.

ROSA, João Guimarães. 2006. Sagarana - O Burrinho Pedrês. Rio de Janeiro: Nova Fronteira.

SARACENO, Elena. 1996. O conceito de ruralidade: problemas de definição em escala européia. Programa de Seminários INEA sobre Desenvolvimento nas áreas rurais: Métodos de análise e políticas de intervenção Roma, 30 de outubro de 1996 (disponível no sitio: http://www.eco.unicamp.br/nea/rurbano/textos/downlo/ruralida.html em 27//7/2006).

SILVA, José Graziano da. 1981, Progresso técnico e relações de trabalho na agricultura. São Paulo: Hucitec.

SILVA, José Graziano da. 1996. A nova dinâmica da agricultura brasileira. Campinas, SP: Unicamp.IE.

SILVA, José Graziano da. 2002, O novo rural brasileiro. Campinas, SP: Unicamp.

VEIGA, José Eli da. 2003. Cidades imaginárias: o Brasil é menos urbano que se calcula. Campinas, SP: Autores Associados.

VEIGA, José Eli da. 2004. Nem tudo é urbano. Cienc. Cult., Apr./June, vol.56, no.2, p.26-29. 